GIS - 理論と応用

Theory and Applications of GIS, 2016, Vol. 24, No.1, pp.39-48

【原著論文】

\title{
形状複雑度を制御可能なネットワーク上の点事象集積領域検出法の提案
}

\author{
井上 亮*・塚原 元英**
}

\section{Spatial Cluster Detection Imposing Constraint on Shape Complexity in Networks}

\author{
Ryo Inoue*, Motohide Tsukahara**
}

\begin{abstract}
Point event cluster detection in networks have been proposed recently; they are suitable for analyses based on detailed location information, as they can describe the micro-space variation of locations of point events at the street level. However, the previous methods lack the flexibility to control the shapes of detected clusters; one can only detect 'circle-like' compact clusters that might include links where point events are scarcely distributed, and the other can only detect complex-shaped clusters that are difficult to interpret their causes. This paper proposes a shape complexity index in networks and a new cluster detection method imposing constraint on the shape complexity based on the proposed index. The application revealed that the proposed method succeeds in controlling the shape complexity of detected clusters in networks.
\end{abstract}

Keywords: 点事象集積検出（cluster detection of point events），ネットワーク分析（network analysis)，形状複䧱度 (shape complexity)

\section{1.はじめに}

行政の透明性向上を目指した情報公開施策に加 え, 公共データの活用を通して市民参加・官民協同 を図り，社会経済の発展を目指す「オープンデー夕」 戦略の推進に伴い, 詳細な位置を記録した様々な空 間データの入手が可能になってきている。市民生活 に密接に関連する空間データの一例として警視庁公 開の「犯罪情報マップ」に着目すると, そこで伝え られる犯罪発生地点に関する情報は, 市民による近 隣の治安状況の確認や, 防犯活動の実施へと活用さ れることが期待される。また，詳細な位置を記録し た空間データの流通は，公的機関が公表するデータ だけに留まらない。測位機能が付いた携帯端末が広 く普及し，詳細な位置や時刻を記録した空間データ を各市民が作成し，それを周囲の人々と容易に共有 できる環境も整っている。

これらの空間データ流通環境に関する現状を鑑み ると, 近い将来, 高い位置精度を有するより多種多
様な空間デー夕を，市民が容易に自由に入手できる 環境が整うことは疑いようがない.しかし, これら の空間デー夕を活用して，各市民が自ら生活する地 域の現状を把握して将来像を描き，他者との議論へ 活用できるようにするには，データの流通促進に加 えて, その分析手法・ツールも合わせて提供するこ とが重要であろう。

さて, 本研究は, 空間データの一つである点事象 データに着目し, 高い空間解像度を有する点事象 データを活用した地域分析手法について検討する。 点事象データとは, 犯罪や事故の発生, 商業施設の 出退店など, 事象 (イベント) の発生場所や時刻を 記録したデータである。点事象の分布データを利用 した地理的集積領域の検出法については数多くの提 案がなされ, 伝染病流行地域（例えば, Kulldorff・ Nagarwalla, 1995; Tango • Takahashi, 2005 ; Duczmal et al., 2006）, 犯罪多発地域（例えば, Duczmal • Assunção, 2004; Shiode, 2011), 産業集積地域の検出

* 正会員 東北大学 大学院情報科学研究科（Tohoku University）

干 980-8579 宮城県仙台市青葉区荒巻字青葉 6-6-06 E-mail : rinoue@plan.civil.tohoku.ac.jp

** 学生会員 東北大学 大学院情報科学研究科 (Tohoku University) 
（例えば, Mori·Smith, 2010; 井上·古郡 , 2013）など, 地域分析に広く活用されてきた。

点事象集積領域の統計的検出法の代表は, Kulldorff・Nagarwalla（1995）が提案した空間スキャ ン統計である。点事象の分析では, デー夕入手可能 性から，行政区域などの地域区分に従って点事象数 を集計した統計デー夕を利用することが多い，空間 スキャン統計では, 通常, 統計デー夕の使用を前提 として各地域を集積検出の最小単位と考え, 隣接地 域の集合で領域を構成し集積として検出する.

これまでに，円や楕円などと重なる地域で構成し た、コンパクトで単純な形状の集積領域を検出す る手法（例えば, Kulldorff, 1997; Tango · Takahashi, 2005; Duczmal et al., 2006）や，地域の隣接関係の みを考えて構成した, 柔軟かつ複雑な形状の集積 領域を検出する手法（例えば, Duczmal · Assunção, 2004; Duczmal et al., 2007; Yao et al., 2011）が提案さ れている。これらの単純あるいは複雑な形状の修正 領域を出力する方法に加えて, 分析者が出力する領 域形状の複雑度を調整できる分析法（Duczmal et al., 2006）も提案されており, 分析者の意図に合わせた 自由度の高い分析ができるようになっている.

また，近年，入手可能になっている高い位置精度 を有する点事象デー夕を利用し，大きな空間縮尺に よる集積領域検出を目指す検討も行われている。 大 縮尺の空間分析で，何らかのネットワークに依存し た現象の分布を分析する場合，ユークリッド距離と ネットワーク距離が大きく異なる場合があるため, 予てからネットワーク構造を踏まえた分析の重要性 が指摘されてきた，例えば，社会経済活動に関する 点事象の空間分布を大縮尺で分析する際に，道路な どの交通ネットワークの構造を無視してユークリッ ド距離を基準に集積領域を検出すると, 誤った結論 を導く可能性があるであろう。そこで，点事象間の 近接性をネットワーク距離で評価し，集積領域を検 出する方法についても検討されている.

Shiode (2011) は，ある地点を中心に一定のネット ワーク距離以内の範囲を集積領域として検出する手 法を提案している。この集積領域の設定は, ユーク リッド平面上の円形領域に対応しており，ネット
ワーク上におけるコンパクトで単純な形状の集積領 域を検出できる。しかし，点事象の集積領域は，常 に単純な形状で表現できるとは限らない。例えば, 大規模店舗が大通りに，小規模店舗はその大通りに 接続する路地に立地している繁華街で，店舗立地を 分析する場合を考えよう。大規模店舗と小規模店舗 はネットワーク距離の短い場所に立地しているもの の，集積している場所は異なる。コンパクトで単純 な形状の集積領域を検出する手法では，距離が近い 路地も含む一連の領域を大規模店舗の集積領域とし て検出する可能性が高く，2 種類の点事象分布の違 いを反映した分析結果を得ることは難しい。

一方，井上・古郡（2013）は，ネットワーク上の 接続リンクの集合として表される，柔軟な形状の集 積領域検出法を提案した。しかし, 空間スキャン統 計は，より広範囲から成る候補領域を高く評価する 傾向があり，意味解釈が困難な複雑な形状の集積領 域が出力される可能性が高い.

このようにネットワーク上の集積検出に関して, コンパクトかつ単純な形状, 柔軟かつ複雑な形状の 領域を集積として検出する手法のいずれにおいて も，領域形状の設定に起因する問題が存在する.

そこで本研究は, Duczmal et al. (2006) が提案し た地域単位の分析において形状複雑度を調整できる 集積領域検出法を参考に，ネットワーク上の分析に おいても形状複雑度を制御して分析ができる集積領 域検出法を新たに提案する。まず，ネットワーク上 領域の形状複雑度を評価する指標を提案した上で, 任意の形状複雑度設定に対応した集積領域検出が可 能な分析法を構築する。最後に，道路ネットワーク 上の商業施設分布データから，集積領域を検出する 提案手法の適用を通して，その有効性を確認する。

\section{2. 点事象集積検出に関する既往研究}

本研究の提案手法を含め, 多くの点事象集積 領域検出法は, 空間スキャン統計（Kulldorff· Nagarwalla, 1995）に基づいている. そこで，2.1 で空間スキャン統計を概説した後，2.2で空間ス キャン統計を用いたネットワーク上の集積領域検出 法を紹介する。 
また，ネットワーク上の点事象集積領域検出にお いて, コンパクトな単純形状から, 柔軟な複雑形状 の領域まで, 様々な形状複雑度の領域を視野に入 れた自由度の高い分析を行うには，まず，領域の 形状複雑度を定量化した上で, その制御が可能な 集積検出手法の構築が不可欠である。 2.3 では，

Duczmal et al.（2006）による，隣接地域の組み合わ せとして構築される候補領域の形状複雑度の評価指 標と, その指標による形状の調整を通して点事象集 積領域を検出する分析法の提案について解説する.

\section{2．1．空間スキャン統計}

空間スキャン統計は, 点密度を基準に, ある領域 に扔ける点事象の集積を評価する。

ここで, 分析対象領域を $G$, 面積や人口などで 規定される領域 $G$ の大きさを $\operatorname{size}(G)$, 点事象数を $\#(G)$ と記す。 また, 集積の候補領域を $Z$, 分析対象 領域 $G$ 内の領域 $Z$ の補領域を $Z^{C}$ と表し, 領域 $Z$ 内 の点密度を $\lambda_{Z}$, 領域 $Z$ 外の点密度を $\lambda_{Z^{\mathrm{C}}}$ と記す.

はじめに，点事象分布が特定の空間点過程に従う ことを仮定する。ここでは点事象分布がポアソン点 過程に従う, 寸なわち, 候補領域 $Z$ 内の点事象数 が $\lambda_{\mathrm{Z}} \times \operatorname{size}(Z)$ を母数とするポアソン分布に従うと 仮定する場合を例に説明する.

次に，ある候補領域 $Z$ に関して，帰無仮説「Z内 外の点密度は等しい $\left.\left(\lambda_{z}=\lambda_{Z^{c}}\right)\right\rfloor$ と対立仮説 $\lceil Z$ 内は外よりも点発生密度が高い $\left(\lambda_{z}>\lambda_{z^{c}}\right) 」$ を立 てる.

ただし，複数の候補領域に関して検定を繰り返す と, 第一種の過誤が生じる確率が高くなる多重検定 問題が生じる。そこで, 空間スキャン統計は, 対立 仮説と帰無仮説の尤度比を用いて, 尤度比最大の 候補領域, Most Likely Cluster (MLC) を抽出した後, その 1 領域のみについて有意性を検定する手順を採 る.

領域 Z に関する尤度比 $L R(Z)$ は式(1)で表される. 上記の分析から得られた MLCの有意性は, モンテ カルロ・シミュレーションを用いて推定した, 帰無 仮説が真の下での点事象分布から得られる MLCの 尤度比分布を用いて検定する。

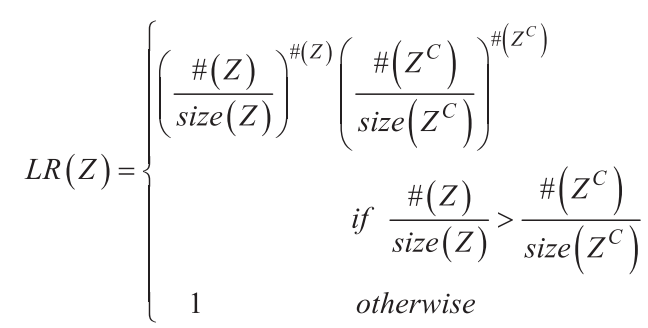

\section{2. ネットワーク上の集積領域検出法}

ネットワーク上の部分領域を候補領域と設定して 空間スキャン統計を適用すると，ネットワーク上の 点事象集積領域を検出できる。ネットワーク上の集 積検出では，点事象はネットワーク上における特定 の空間点過程に従い分布することを仮定する.

Shiode（2011）は，ネットワーク上の任意地点か ら一定ネットワーク距離内の範囲を候補領域と設定 し，ネットワーク上でコンパクトな集積領域を検出 する手法を提案した。 シミュレーションデータや, ニューヨーク州バッファロー市における麻薬取引や 路上強盗の発生地点デー夕を用いて集積領域を検出 する実験を行い，ユークリッド距離に基づく候補領 域設定では適切に分析できない，道路に沿って集中 して発生する点事象の分析に有効であることを確認 した。また，その拡張として，Shiode·Shiode（2013） は，ネットワーク上の位置に加えて時間も考慮した 集積検出に関する検討も行っている。しかし, これ らの分析手法の限界として，ネットワーク上におけ る単純な形状の集積領域しか分析できないため, 点 事象分布が少ない領域を集積領域に含んだ結果を出 力する可能性があることが挙げられる.

井上・古郡（2013）は，ネットワークを構成する 各リンクを集積検出の最小単位と考え, 接続するリ ンクで構成される領域を候補として, ネットワーク上 で柔軟な形状の集積領域を検出する方法を提案した。 仙台市青葉区内の商業施設の集積検出を行い, 分析 の有効性を評価している. しかし，その限界として， 形状の自由度が高いために，ネットワーク上で複雑 に繋がる広い領域を覆うリンクの集合を集積領域と して検出する場合があり, 分析者にとり解釈が難し い結果が得られる可能性があることが挙げられる. 
2. 3. 形状複雑度の調整が可能な集積領域検出法

Duczmal et al.（2006）は，地域単位の分析に関し て領域形状の複雑度を評価する指標を導入した上 で, 検出される集積領域の形状複雑度を調整できる 分析法を提案した.

提案された形状指標は, 領域 $Z$ の面積 $\operatorname{area}(Z)$ と, その凸包と等しい外周長 circum_CH(Z) を持つ円の 面積の比で定義される。領域 $Z$ の形状指標 $K(Z)$ は

$$
K(Z)=\operatorname{area}(Z) / \pi\left(\frac{\text { circum_CH }_{-}(Z)}{2 \pi}\right)^{2}
$$

で表され，領域Zが円に近い単純形状なら1に，複 雑形状なら0に近い值をとる.

集積領域の検出では，空間スキャン統計で用いる 尤度比 $L R(Z)$ の代わりに, 形状指標值 $K(Z)$ と正の パラメータ $\alpha$ を加えた $L R(Z)^{K(Z) \alpha}$ を最大とする候補 領域を抽出する，パラメータ $\alpha$ に大きな值を設定す ると, 円に近い単純形状の領域が高く評価される. 分析者がパラメー夕 $\alpha$ の值を変更することで, 検出 される集積領域の形状複雑度を調整できる。ただし， パラメータ $\alpha$ の值と, 検出される集積領域形状との 関係は明確ではない.

\section{3. 形状複雑度を制御可能なネットワーク上の 集積領域検出法の提案}

本章では，ネットワーク上領域の形状複雑度を制 御した集積領域検出法を提案する.まず, 3.1 では, ネットワーク上領域の形状複雑度を定量化する指標 を新たに導入する。次に，3.2では，その形状指 標を用いて領域形状に制約を設定した上で，集積領 域検出を行う提案手法を示す.

さて, 都市では, 土地利用の計画や規制, 建築物 への規制が街路に沿って設定されることが多く, 結 果として街路毎に社会経済活動形態が異なる地域が 形成されてきた。 そのため, 街路単位や, 街路を交 差点で分節した街路区間単位に, 都市内の社会経済 活動を分析することが一定の妥当性を有する。

また，点事象間距離に基づく分析では，沿道環境 を考慮した分析への拡張は難しい. しかし, 街路区 間の点事象数集計值に基づく分析を前提とすると, 接道建物の延床面積など, 沿道環境を表す属性を街
路区間の大きさの定義に利用することにより，沿道 環境の違いを踏まえた点事象分布分析が可能になる.

そこで本研究では, 分析対象の街路ネットワーク を構成する交差点間区間（リンク）を集積検出の最 小単位とし，接続するリンクの集合を候補領域とし て考えることを前提とする。なお，各点事象は，最 寄りのリンクに割り付けて分析する.

\section{1。ネットワーク上領域の形状指標の提案}

ネットワーク上領域 Z の形状複雑度は, 領域 $Z$ と, それに対応した同一総リンク長を有する単純形状領 域 $\operatorname{Compact}(Z)$ の比較による基準化を通し評価する.

まず,ネットワーク上の「単純形状領域」は, ユー クリッド平面上の円の定義に対応し, Shiode（2011） が候補領域の設定に用いている，「ある点から一定 のネットワーク距離内の領域」として定義する。 た だし, 分析対象領域のネットワーク形状は一様で ないため, 領域 $Z$ とそれに対応した単純形状領域 Compact $(Z)$ を適切に比較するためには, 領域 $Z$ が 位置する場所と同地域のネットワーク上に，単純形 状領域を構成しなければならない。

そこで, ネットワーク上領域の中心を, ユークリッ ド平面上のある領域に関する最小包含円の中心が有 する性質の一つ,「領域内のすべての点までの最長 距離が最短である点」に倣い定義する。すなわち， ネットワーク上領域の中心を「領域内のすべての点 までの最長最短経路長が最短である点」として定義 する。ただし，前述の通り，本研究はリンクを分析 の最小単位とし、リンクの分割は考えないので, 中 心の定義を「領域内の任意のノードまでの最長最短 経路長が最短となるノード」と簡略化する.

例えば，図1(a) 上に太線で表された領域 $Z$ が与 えられたとしよう。まず，領域内のノードのすべて の組み合わせについて最短経路探索を行い, 各ノー ドからの最長最短経路長を記録する。その後，上記 の定義に従い, 図1(a)の白点で表された，その值 が最小のノードを中心ノード $\operatorname{Center}(Z)$ とする。次 に, 中心ノード Center $(Z)$ を基準に, 総リンク長が 領域 $Z$ の総リンク長を超えるまで, 中心ノードに 近い順にリンクを連結し，領域 $Z$ に対応した単純 
形状領域 Compact(Z) を構成する（図 1(b) 太線）.

次に，形状複雑度を，ユークリッド空間上の最小 包含円半径に相当する,「領域の中心ノードからの 最長の最短経路長」を基準に評価する。ユークリッ ド平面上では, コンパクトな単純形状領域の最小包 含円半径は, 同一面積の円の半径に近い值となるが, 複雑形状領域の最小包含円半径は大きくなる。 ネッ トワーク上でも同様に, 複雑形状領域では, 中心ノー ドから他のノードまでの最大最短経路長は長くなる (図 1 の矢印)。本研究ではこの性質を利用し, 形状 指標の設定に用いる.

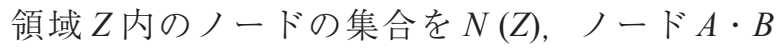
間の最短経路長を $n d(A, B)$ と表すと, 領域 $Z$ の形 状指標 $K n(Z)$ は式 (3) と表される。

$K_{n}(Z)=\frac{\max _{n \in N(\text { Compact }(Z))} n d(n, \text { Center }(\text { Compact }(Z)))}{\max _{m \in N(Z)} n d(m, \text { Center }(Z))}$

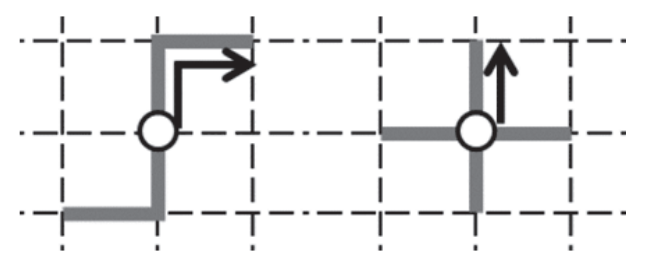

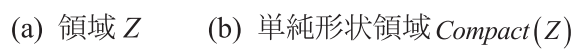

破線: 分析対象ネットワーク, 太線: 領域,

白点: 中心ノード,

矢印: 中心ノードからの最長最短経路長

図1 形状指標值 $K_{n}(Z)$ の算出

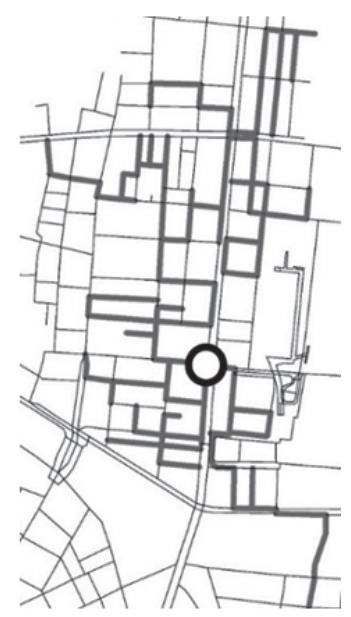

(a) 複雑 $K_{n}(Z)=0.30$

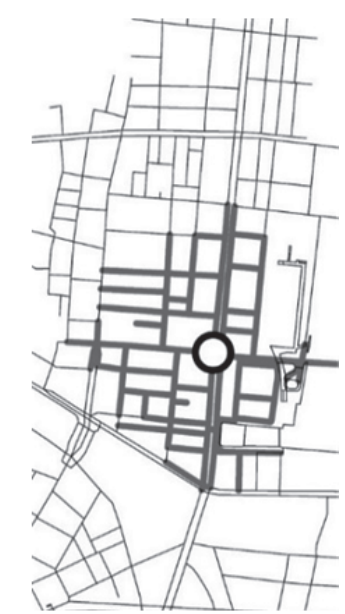

(b) 単純 $K_{n}(Z)=1$
太線: 領域 Z, 白丸: 中心ノード

図2 領域形状と形状指標 $K_{n}(Z)$ の関係
領域形状が複雑なら形状指標 $K_{n}(Z)$ は 0 に近づき, 単純なら 1 に近づく. 図 2 は, 領域形状と形状指標 值の関係を示す。 (a) と (b) の総延長・中心ノードは 等しいが，(a)は複雑な形状を示すのに対し，(b) は 本研究の単純な形状の定義に従った形状を示す.

なお, 領域 $Z$ の最大最短経路長は, 中心ノード の探索過程で求まり, 単純形状領域 $\operatorname{Compact}(Z)$ の 最大最短経路長は, その領域の構成過程で求まる.

\section{2. 形状制約を設定したネットワーク上の 集積領域検出}

前節で提案した形状指標を利用して領域形状に 対する制約を設定した上で，遺伝的アルゴリズム (GA) を用いて集積領域を検出する方法を提案する. Duczmal et al.（2007）は, GAによる地域単位・柔 軟形状の集積領域検出を提案しており, 本研究では この応用によるリンク単位の集積検出を検討する.

GA の分析で用いる各個体は集積候補領域を表 し, その染色体情報として候補領域を構成するリン ク集合を記録している。形状制約を設定した下での 集積領域検出手順を以下に示す。

a) 初期世代の生成

分析対象ネットワークの点事象が存在する全リ ンクを用い，初期世代を 1 個体ずつ生成する。ま

ず，各個体に接続するリンクを無作為に選んで結 合し領域を拡大する。ただし, より集積性の高い 個体を生成するため, 選ばれたリンクに点事象が ない場合は, 確率的に結合する。この結合操作 は，個体のリンク数が閾值に達するか，もしく は, 個体の尤度比が闇值を下回るまで繰り返す。

b）交叉

世代から2個体を無作為に選び，両者に共通のリ ンク群があれば，それらを核として交叉を行う。

まず, 各親について, 核への連結次数の昇順で リンクの表を作成する。ただし，同一連結次数の リンクは無作為に並べる。

次に，核に対して両親のリンクを表の順序に結 合し，子を生成する，両親の核以外のリンク数が それぞれ $m, n$ なら $m \times n$ 種類の個体を生成し, 形 状指標值が制約を満たすもの全てを子とする. 
c) 淘汰

b）の交叉方法からは, 同一の両親から多数の 子が生成されるため, 子だけで世代を構成すると 個体の多様性が失われてしまう。そこで, 本研究 は, 親世代の個体のうち, 尤度比下位の一定割合 のみを，子世代の尤度比上位の個体で更新する。

最大尤度比を示す個体が一定世代間更新されな くなるまで交叉と淘汰を繰り返した後, その個体 をMLCとして出力する。 その有意性は, モンテ カルロ・シミュレーションで求めた無作為点分布 から得られる最大尤度比分布と比較し検定する。

\section{4. 提案手法の実行可能性の検証}

提案手法の実行可能性を, 道路ネットワーク上に おける商業施設立地の集積領域検出を通し検証す る. 分析対象地域は, 仙台市青葉区のうち東北自動 車道東側の市街地で, 居酒屋の立地を分析する. 道 路ネットワークデータは数值地図 25000 を利用し, 総延長 $647 \mathrm{~km}, 7,953$ リンクで構成されている. 居 酒屋位置デー夕は, 座標付き電話帳「テレポイント (R) Pack!」 2010 年 9 月版を利用し, 492 店舗存在する. なお，各店舗は最寄りのリンクに立地していると仮 定し、リンク毎に店舗数を集計したデータを作成し

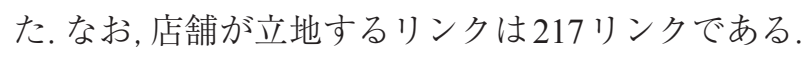

GA のパラメータ設定を以下に示す。初期世代生 成は, 点事象がないリンクの結合確率を $1 / 3$, 個体

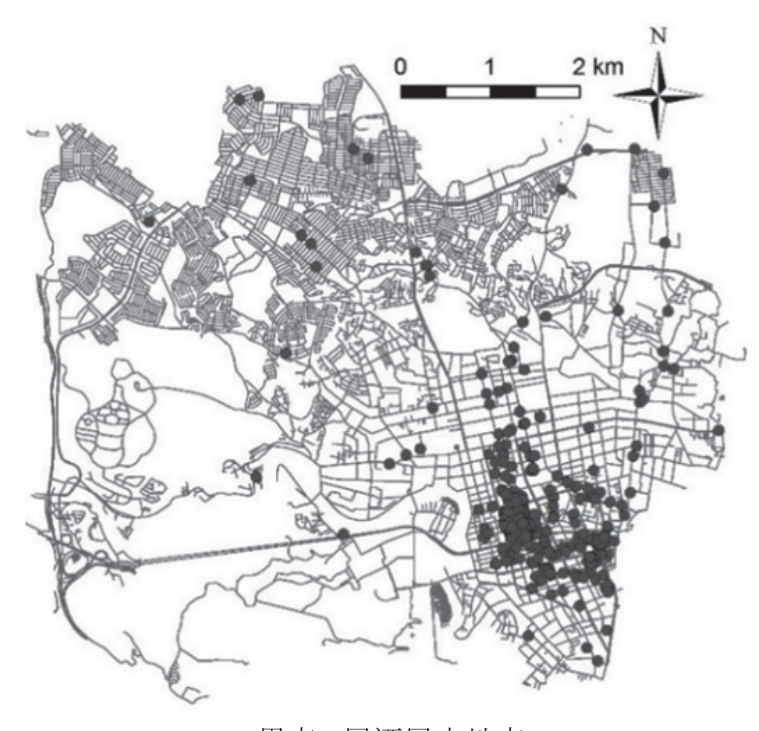

黒点: 居酒屋立地点

図3 分析対象の居酒屋立地点と道路ネットワーク
拡大終了となるリンク数上限は店舗立地リンク数, 対数尤度比の下限は 5 とした。 なお, 後述するが, リンク数上限が小さい, あるいは, 対数尤度比下限 が大きい場合は，狭い領域で構成される初期世代が 生成され, 対数尤度比が小さい局所解に陥る可能性 が高い。また，リンク数上限が大きい場合，ほぼ同 じ領域を覆う多様性のない初期世代が生成される可 能性がある。そのため, 初期世代生成に関するパラ メー夕は，広い領域を覆うが多様性を有する初期世 代の個体群を生成できるように設定した。淘汰で は，親世代の $10 \%$ の個体を子世代の個体で更新し た。 また，交叉・淘汰の終了条件は，最大尤度比の 個体が 10 世代続いて更新されない場合とした。

本検証では，まず，領域の大きさを総リンク長と 設定した分析を行った。はじめに，ネットワーク上 の店舗分布がポアソン点過程に従うとの仮定の下, 帰無仮説「店舗密度は候補領域内外で等しい」, 対 立仮説「店舗密度は候補領域内が外よりも多い」を 立て，GAを用いてMLCを探索する. 次に，モン テカルロ・シミュレーションで, 帰無仮説の下での 各リンクの店舗数を模擬して集積領域の検出過程を 1000 回繰り返し, MLCの棄却域を定めた。形状制 約なしの集積検出の場合, 有意水準 1\%の片側検定 による菓却域は対数尤度比 24.5 以上となった。

ここで, 複数の形状制約を設定し, 居酒屋店舗集 積領域を検出した結果を図 4 と表 1 に示す。図 4 上 の赤線は, 各制約下で検出された集積領域を示す.

いずれの検出結果も対数尤度比が高く, 有意な点 事象集積領域が抽出されている. 全店舗の約 $5 \sim 7$ 割が約 $1 \%$ 前後の長さの領域に集中して立地する結 果が得られており, 点事象集積領域の検出結果して 妥当性を有すると言えよう。また，領域内外の点密 度の比を表す相対リスクは，いずれの検出結果でも 高い值を示している.

ここで，各制約下での分析結果に着目する.

井上·古郡 (2013) と類似の結果が得られる, 形 状制約を課さない分析（図 4(a)）では，仙台駅前か ら東西・南北に走るアーケードを通り, 市内随一の 繁華街である国分町まで続く, 複雑な形状の広い集 積領域を検出した。対数尤度比は最大だが, 店舗密 


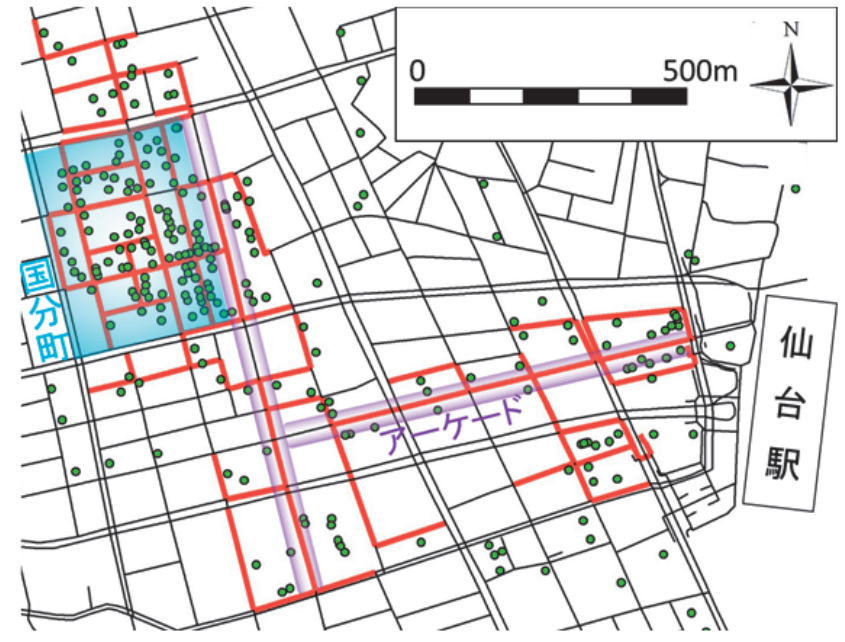

(a) 形状制約なし

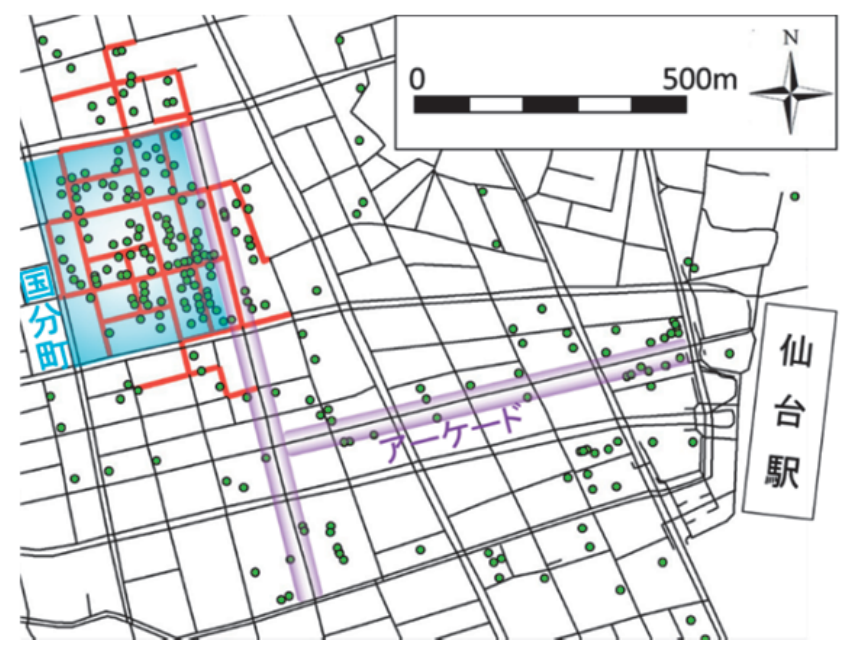

(c) 形状制約 $K_{n} \geqq 0.8$

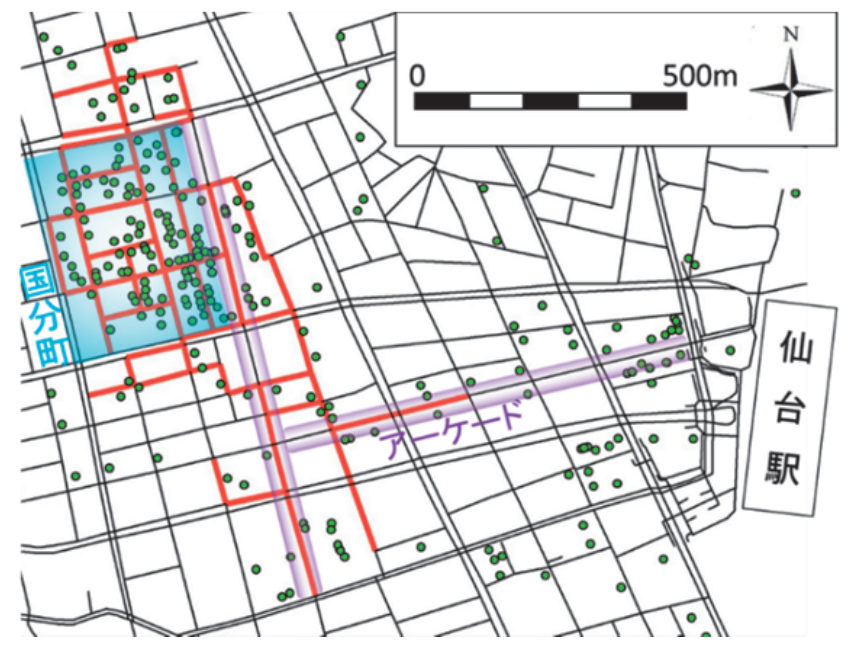

(b) 形状制約 $K_{n} \geqq 0.6$

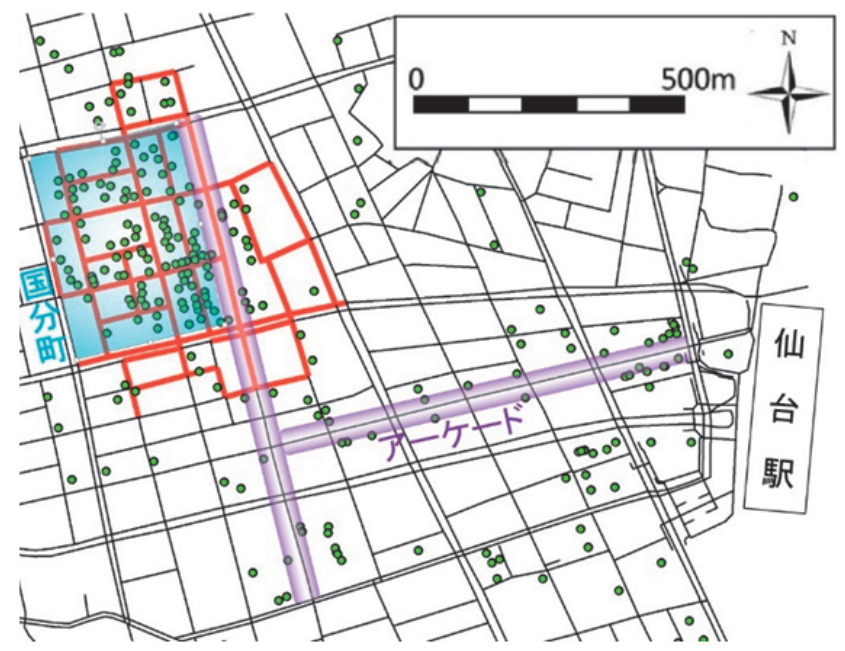

(d) 形状制約 $K_{n} \geqq 0.9$

緑点: 居酒屋立地点, 赤線:集積検出領域

図4 集積領域の検出結果

表 1 集積領域の検出結果

\begin{tabular}{|c|c|c|c|c|c|c|c|}
\hline 形状制約 & $\begin{array}{c}\text { 集積領域 } \\
K_{n}\end{array}$ & $\begin{array}{l}\text { 対数 } \\
\text { 尤度比 }\end{array}$ & $\mathrm{p}$ 值 & $\begin{array}{c}\text { 店舗数 (店) } \\
\text { (割合) }\end{array}$ & $\begin{array}{c}\text { 総延長 }(\mathrm{km}) \\
\text { (割合) }\end{array}$ & $\begin{array}{l}\text { 相対 } \\
\text { リスク }\end{array}$ & $\begin{array}{c}\text { 店舗密度 } \\
(\text { 店/km) }\end{array}$ \\
\hline (a) なし & 0.35 & 1,201 & 0.001 以下 & $\begin{array}{c}350 \\
(71 \%)\end{array}$ & $\begin{array}{c}8.99 \\
(1.4 \%)\end{array}$ & 174 & 38.9 \\
\hline (b) $K_{n} \geqq 0.6$ & 0.60 & 924 & 0.001 以下 & $\begin{array}{c}270 \\
(55 \%)\end{array}$ & $\begin{array}{c}6.03 \\
(0.93 \%)\end{array}$ & 129 & 44.8 \\
\hline (c) $K_{n} \geqq 0.8$ & 0.81 & 867 & 0.001 以下 & $\begin{array}{c}241 \\
(49 \%)\end{array}$ & $\begin{array}{c}4.32 \\
(0.67 \%)\end{array}$ & 142 & 55.8 \\
\hline (d) $K_{n} \geqq 0.9$ & 0.90 & 802 & 0.001 以下 & $\begin{array}{c}242 \\
(49 \%)\end{array}$ & $\begin{array}{c}5.80 \\
(0.90 \%)\end{array}$ & 107 & 41.7 \\
\hline 全領域 & - & - & - & 492 & 647 & - & 0.764 \\
\hline
\end{tabular}


度は最低である。これは, 空間スキャン統計の尤度 比基準は, より多くの点事象を含むより広い領域に おいて, 内外の点密度に差があることをより高く評 価するためである。形状制約がない分析では, 点密 度が特に高い集積の核となる領域に, 周辺領域を結 合して広い集積領域を検出する.

形状制約を強めるにつれて集積領域が縮小し, 領 域形状がコンパクトになることが確認できる（図 4(b)(c))．形状制約を置いた分析では周辺領域を自 由に結合できないため, 領域は狭く尤度比は小さい が, 点密度が高い領域が検出されることが多い，た だ，形状には自由度があるため，点のないリンクは 含まない集積領域が検出されている。一方, Shiode （2011）と類似の結果が得られる, 最も強い形状制 約を課した場合（図 4(d)）は，形状はコンパクトだ が, 点が存在しないリンクも集積領域に含まれてお り，点密度や相対リスクが低下している。

以上のように，提案手法では，分析者の形状制約 に対する設定に従って検出する集積領域の形状複雑 度を制御可能で, 点がないリンクを含まないコンパ クトな領域も検出可能なことを確認した.

以上では，リンク長を領域の大きさと設定した分 析例を示したが, 前述の通り, リンク単位の集積検 出を前提とした提案手法では，沿道環境を表すリン ク属性を考慮した分析を容易に実行できる。その一 例として，接道する建物の延床面積を領域の大きさ とし, 店舗集積を検出する, なお, 沿道建物の延床 面積は, 株式会社ゼンリンが発行した ZmapTownII 2008/09 年度版を用いて, 建物ポリゴン面積に階数 を掛けた值として延床面積を設定し，建物ポリゴン の重心に最も近いリンクにその值を割り当てた。な お，階数が記録されていない場合は，建物ポリゴン の面積を延床面積とする.

沿道建物の単位延床面積あたりの店舗数がポアソ ン分布に従うとの仮定の下, 帰無仮説を「沿道建物 延床面積当たりの店舗数は領域内外で等しい」, 対 立仮説を「沿道建物延床面積当たりの店舗数は領域 内が外より多い」とし，形状制約を課さず集積検出 を行った結果を図 5 ・表 2 に示す．駅前など店舗が 多く立地する都心部は高層建築が多く延床面積が広
いため, 尤度比・相対リスクは低下したが, 図 4(a) とほぼ同じ領域を検出した。リンク単位などで集計 した点事象数を用いた分析では，沿道環境を踏まえ た集積検出も簡単に実行できることが確認できた.

さて，形状制約を課した分析では，制約のない場 合に比べ検出集積領域は狭い。しかし，形状制約設 定時に集積領域から外れる領域は，点事象集積領域 ではないことを必ずしも意味するわけではない.

ここで, 形状指標の下限を 0.8 とした制約を課し, 集積領域検出を 3 回繰り返した結果を図 6 に示す. ただし，空間スキャン統計では，多重検定問題を回 避するために, 同時に複数箇所の集積領域検出を行 うことはできない. そこで Zhang et al. (2010)に従い, 2 箇所目以降の集積領域は, 既検出の集積領域が存 在するとの条件付きで分析するため, 既検出の集積 領域を分析対象から除外して提案手法を適用した。

図 6 上の赤線は 1 回目, 青線は 2 回目, 緑線は 3 回目の検出領域を示す。これら 3 箇所の集積領域を 合わせると，形状制約なしで検出された領域（図 4(a)）とほぼ同じ領域と一致することが分かる。す なわち，形状制約のない分析では，一連の広い集積 領域として抽出されるのに対し, 強い形状制約を置 いた分析では，3種類のコンパクトな領域の集合体 として集積が検出される。空間スキャン統計を用い た有意性検定を経たこれらの結果は，いずれの解釈 も成立するため，分析者は，形状制約を制御し，よ り意味解釈が容易な結果を得ることができる。この ように, 提案手法は点事象集積検出の自由度を高め ることができると言えるであろう.

ただし，空間スキャン統計を用いた複数箇所の 集積検出結果の解釈には注意を要する．Zhang et al. （2010）の手法では，各回の分析条件はすべて異な るため, 得られた結果を横並びで解釈することは適 切ではない。 そこで, Mori・Smith(2010) は, 空間 スキャン統計による単一集積領域の有無に関する検 定仮説を複数集積領域の分析に拡張し, ベイズ情報 量規準 (Bayesian Information Criterion: BIC) に基づ くモデル選択の枠組みで，同時に複数の集積領域を 検出する方法を提案している。 しかし, 複数集積領 域の候補を検索する過程は，地域単位の分析でも計 
表 2 沿道建物延床面積あたりの店舗集積検出結果

\begin{tabular}{c|cc}
\hline & 集積領域 & 全領域 \\
\hline 集積領域 $K_{n}$ & 0.36 & - \\
対数尤度比 & 773 & - \\
$\mathrm{p}$ 值 & 0.001 以下 & - \\
店舗数 (店) & 331 & 492 \\
建物総床面積 $\left(\mathrm{m}^{2}\right)$ & $9.3 \times 10^{5}$ & $2.4 \times 10^{7}$ \\
相対リスク & 51.0 & - \\
店舗密度 $\left(\right.$ 店 $\left./ \mathrm{m}^{2}\right)$ & $0.3 \times 10^{-3}$ & - \\
\hline
\end{tabular}

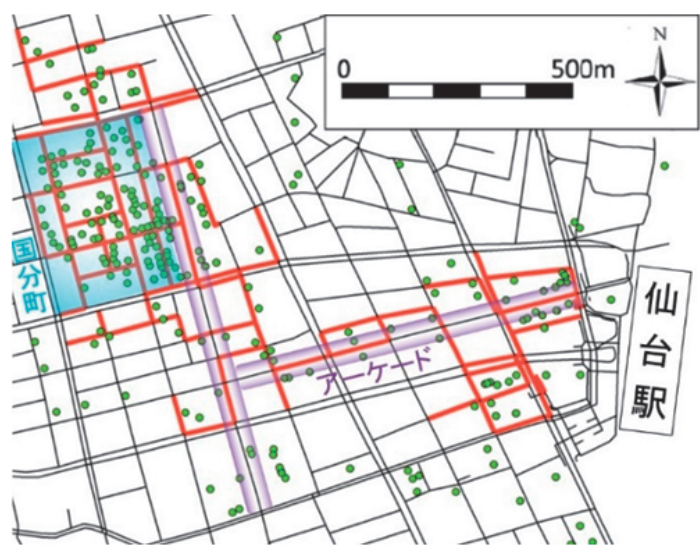

緑点: 居酒屋立地点, 赤線:集積検出領域

図5沿道建物延床面積あたりの店舗集積検出結果

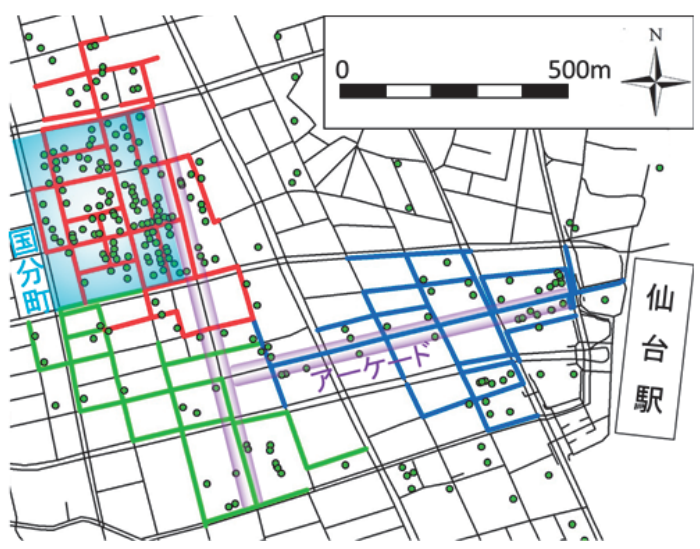

緑点: 居酒屋立地点, 赤線: 第 1 集積領域 青線: 第 2 集積領域, 緑線: 第 3 集積領域 図6 複数集積領域の検出結果 $\left(K_{n} \geqq 0.8\right)$

算負荷が大きく，ネットワーク上のリンク単位の分 析への適用は難しいと予想される，以上のように， 空間スキャン統計に基づく複数集積領域の同時検出 には，限界が存在することには注意が必要である。

\section{5.おわりに}

本研究は, 接続リンク集合で構成された領域の形
状評価指標を提案し, 指標值に関する制約の下,ネッ トワーク上の点事象集積領域検出法を構築した.

既往のネットワーク上の点事象集積領域検出法で は，任意点から一定のネットワーク距離以内の単純 かつコンパクトな形状の領域, あるいは, リンクの 接続関係のみを考慮して構成した柔軟かつ複雑な形 状の領域のいずれかしか検出できなかった，単純形 状の集積検出では, 結果の解釈が容易なまとまった 集積領域が検出されるが，点事象のないリンクもそ の領域に含まれる場合がある。また，柔軟形状の集 積検出では，分析者にとり解釈が難しい複雑な形状 の集積領域が検出される可能性がある.

一方, 本研究の提案手法は, 形状指標に対して任 意の制約を課し，集積領域形状を制御した分析が可 能である。その結果，例えば，コンパクトな形状で 点事象のないリンクを含まない集積領域や，柔軟な 形状で点密度が高い集積領域を検出できる可能性が ある、検出集積領域に制約を課す手法として提案さ れている，相対リスクを考慮した制限付き尤度比統 計量（Tango, 2008）などとは異なり，相対リスクや 点密度が高い領域を直接的に検出することはできな いが，集積領域形状を考慮し，分析者にとり解釈が 容易な集積領域の探索を可能にしており，ネット

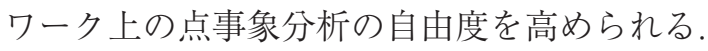

なお, 提案解法は, GA を用いて尤度比最大の領 域を探索する，特に，多数のリンクから構成される 広い領域が大域的最適解である場合は，その近傍に 達することが難しいと予想され，限界を有する．

また前述の通り，空間スキャン統計に基づく本 手法は, 多重検定問題回避のため同時に一集積 領域しか検出できない. 一方, Caldas de Castro • Singer(2006), Catelan • Biggeri(2010), Brunsdon • Charlton(2011） は, False Discovery Rate 制御 法 (Benjamini・Hochberg, 1995)に着目し, 地域単位の 分析で複数の点事象集積領域の同時検出に応用して いる，ネットワーク上のリンク単位の分析では，各 リンクに対応する空間領域が狭く点事象数の期待值 が小さいため, その応用には困難が予想されるが, ネットワーク上の同時複数集積領域検出は重要な検 討課題である。また，集積検出法の提案では検出力 
の議論を通常行うが, 領域形状を考慮する本手法の 検出力評価に用いるべきシミュレーション設定には 多くの議論を要するため, その検討は今後の課題と する. 加えて本研究では, 点事象の分布としてポア ソン点過程を仮定した分析を行っているが，例えば Zhang・Lin (2014)など，より一般的な点事象分布を 仮定した点事象集積検出手法も提案されている。こ れらを踏まえた拡張も今後の検討事項としたい.

\section{謝辞}

本研究は科研費 24241053 の助成による成果であ る。東京大学空間情報科学研究センターの空間デー 夕利用に伴う共同研究（No. 456）により, 座標付 き電話帳「テレポイント $\mathrm{R}$ P Pack!」を利用した.

\section{参考文献}

井上 亮, 古郡美佳 (2013) リンクの接続関係を利用 したネットワーク上の点事象集積領域の検出法の開 発.「土木計画学研究・講演集」, 47, CD-ROM.

Benjamini, Y. and Hochberg, Y. (1995). Controlling the false discovery rate: a practical and powerful approach to multiple testing. Journal of the Royal Statistical Society Series B, 57 (1), 289-300.

Brunsdon, C. and Charlton, M. (2011) An assessment of the effectiveness of multiple hypothesis testing for geographical anomaly detection. Environment and Planning B: Planning and Design, 38, 216-230.

Caldas de Castro, M. and Singer, B.H. (2006) Controlling the false discovery rate: a new application to account for multiple and dependent tests in local statistics of spatial association. Geographical Analysis, 38, 180-208.

Catelan, D. and Biggeri, A. (2010) Multiple testing in disease mapping and descriptive epidemiology. Geospatial Health, 4 (2), 219-229.

Duczmal, L. and Assunção, R. (2004) A simulated annealing strategy for the detection of arbitrarily shaped spatial clusters. Computational Statistics and Data Analysis, 45, 269-286.

Duczmal, L., Kulldorff, M., and Huang, M. (2006) Evaluation of spatial scan statistic for irregularly shaped clusters. Journal of Computational and Graphical Statistics, 15 (2), 428-442.

Duczmal, L., Cançad, A., Takahashi, R., and Bessegato, L. (2007) A genetic algorithm for irregularly shaped spatial scan statistics. Computational Statistics and Data Analysis, 52, 43-52.

Kulldorff, M. and Nagarwalla, N. (1995) Spatial disease clusters: Detection and inference. Statistics in Medicine, 15, 707-715.

Kulldorff, M. (1997) A spatial scan statistic. Communications in Statistics-Theory and Methods, 26, 1481-1496.

Mori, T. and Smith, T. (2010) A probabilistic modeling approach to the detection of industrial agglomeration. KIER Discussion Paper, 777, 1-54.

Shiode, S. (2011) Street-level spatial scan statistic and STAC for analysing street crime concentrations. Transactions in GIS, 15 (3), 365-383.

Shiode, S. and Shiode, N. (2013) Network-based spacetime search-window technique for hotspot detection of street-level crime incidents. International Journal of Geographic Information Science, 27 (5), 866-882.

Tango, T. (2008) A spatial scan statistic with a restricted likelihood ratio. Japanese Journal of Biometrics, 29(2), 75-95.

Tango, T. and Takahashi, K. (2005) A flexible shaped spatial scan statistic for detecting clusters. International Journal of Health Geographics, 3, 17.

Yao, Z., Tang, J., and Zhan, B. (2011) Detecting of arbitrarily shaped clusters using a neighbor-expanding approach: A case study on murine typhus in South Texas. International Journal of Health Geographics, 10, 23.

Zhang, Z., Assunção, R., and Kulldorff, M. (2010) Spatial scan statistics adjusted for multiple clusters. Journal of Probability and Statistics, Article ID 642379. Zhang, T. and Lin, G. (2014) Family of power divergence spatial scan statistics. Computational Statistics and Data Analysis, 75, 162-178.

（2015年9月14日原稿受理, 2016年3月15日採用決定, 2016年5月16日デジタルライブラリ掲載) 